\title{
INTERVIEW
}

\section{HANA MACHKOVÁ: COOPERATION WITH STUDENTS PAYS OFF FOR COMPANIES}

Prof. Hana Machková is the new rector of the University of Economics, Prague and member of the CEBR Scientific Board. In this interview for Central European Business Review, she talks about her goals and priorities in leading one of the most prestigious economic universities in the CEE region, about cooperation between universities and companies and about other interesting topics.

What are your hobbies? If you weren't rector, what would you like to become?

You probably will be disappointed at my answer but my biggest hobby is my job. I have never wanted to be anything else but a teacher. Since my childhood, I was playing teacher, and I was brought up in a family of teachers. My big interest is France and anything connected to France, and French as a language. If I was not the rector, most likely I would be the vice-rector such as during the last eight years when I was responsible for international relations and PR. The University of Economics has achieved very good results in the area of internationalization, for example in the bachelor's or master's study programs in English. Or, I would continue managing the French-Czech Institute of Management, which I established in 1990. It was the very first international project of the university. Most likely I would be visiting France, would take care of my 91-year old mother. I would also be trying to write more.

When speaking about France - which region is your favorite? And do you cook?

I enjoy cooking very much, and I think that I cook well. It is my habit to invite friends and fellow colleagues for dinner in France. I cannot say that I treat my Czech colleagues very often with dinner, but I very often host my international colleagues both French people and also others if, for example, there are guest professors here and I want to make a good impression on them. As a proper Czech citizen, I have to admit that I do not enjoy cooking hot dinners - I do not treat my husband very often with them - but on Sundays, both our sons come for dinner, and then I cook of course. They do not live with us under one roof anymore so I also prepare take away meals for them too. When the guest professors come, then I cook as the French do - big dinner with a nicely set table and numerous courses, mostly roasted duck or 'svíčková' as Czech classical cuisine is very popular with foreigners. Unfortunately, I am not very good at preparing desserts, so my mother prepares these. Thus I enjoy cooking very much.

Let's imagine that it is March 2018 and your term as rector is over. What has happened during these four years?

When speaking about our university, I wish we had a significantly higher number of young docents and professors - therefore, this is my main goal - more young, talented and skilled lecturers. I would like it if they would not have to wait long for docentship and we would have at least 60 percent of the professors under age 60. I also wish that the university would have more international accreditations, and that we maintain the EPAS accreditation which we obtained for the International Trade and International Business programs. I would be glad if the university becomes truly international and if we would succeed in admitting even more students into foreign-language subjects and if we could be more selective regarding this, so that the University of Economics would be the leader in CEE.

And what is the current position of the University of Economics, Prague?

Our position is already favorable; however, it will become more and more difficult because universities from other countries, e.g. Poland or Hungary, also have high 
ambitions. These universities are attempting to offer an increasing number of possibilities of education in English; therefore, the environment is incredibly competitive. In case we succeed and become a university that is appreciated by students both from European countries and North America - that would be a huge success. I would like it if we had an MBA in English running for at least two years by the end of my term.

\section{What should a university offer to a student nowadays? What should be the main value added for the students?}

University studies differ from other types of educational institutions because it offers some sort of guideline for thinking, but not for manual use. Our students should become educated managers who will master practical subjects; however, they also need theoretical background. They need to have language skills, not only English, but they should have knowledge of a second foreign language, too. They should be more mobile than now because Czech people usually have problems with moving abroad and seeking experience there. Also, I would like to have students gain practical experience to a higher extent. It is surprising that under Socialism there used to be obliga-tory internships in companies, which is not practiced in Capitalism. It is a big disadvantage for the students because then they need to work, e.g. part-time, and they do not attend classes. If internships would become an accredited component of education, at least within the business focused studies that prevail, it would be appropriate. Nowadays, these are more often exceptions than the rule. It is surprising, but there is a big dislike within the university towards internships from many faculties as well as from our students who claim that we want to make our work easier. Companies would be interested; however, Czech legislation does not address the concept of an internship. Therefore, there are no benefits for companies; contrast this to the situation in France, where such companies benefit from a tax advantage. It is much easier for companies to employ a student via an employment agreement. Our credit system enables students to concentrate classes into 2-3 days which provides enough time for work, but I believe that it would be better if it were be an inseparable part of the educational system.

\section{What, in your opinion, attracts students in fact and what do they expect from the university?}

It depends on the subject. The University of Economics offers two branches. Students and subjects that are business focused and economic-quantitative subjects. If we consider the mainstream, then I think students want to learn things that would be useful in practice so that they would able to work in a company (a significantly smaller part wants to work in the public domain, i.e. mainly students from the Faculty of Economics). There are also a significant number of students who start to run their own businesses. The students expect us to open the doors into the business world for them.

\section{And what do the companies expect?}

The companies expect students who will be independent, flexible, language skilled and used to working hard.

\section{How about tighter connections between companies and universities in the area of research, etc.?}

Our cooperation with companies is relatively extensive. Our partnership structure has grown during the last eight years. The companies are particularly interested in cooperation; we receive offers for lectures, project management, etc. It is optimal for us to focus on our partners - but not only because of their sponsorship, these are not tremendously high amounts - the only partner that provides us with really high sums is our main partner, Česká spořitelna. Here we have a long-term and mutually important cooperation but it also represents a commitment and public claim of the company towards the university. We can also cooperate in the area of PR and marketing with logos and co-branding... It is a good thing to have relationships based on a contract, which surprisingly is unpopular with companies. In the case that we have good long-term relationships, we are able to execute projects in the area of applied research. For example, Škoda Auto has entrusted us with very interesting projects, e.g. in the area of marketing (Simply Clever concept) and we have cooperated on pricing, which represent very interesting areas.

\section{How can a company benefit from cooperation with the university? Is there any potential in improving their own business?}

They can, for example, recruit and hire the most talented students, which they encounter during work on projects. Companies get ideas from young people. If you could see the personal involvement of the CEO of Škoda Auto, Mr. Vahland (probably the best known manager in CR), and how our students were presenting the project in front of the whole board where there were only German people present. They came here from all over the world just because of that, and then we had a big presentation in Karlovy Vary for dealers worldwide. According to Mr. Vahland, the biggest benefit lies exactly in getting fresh 


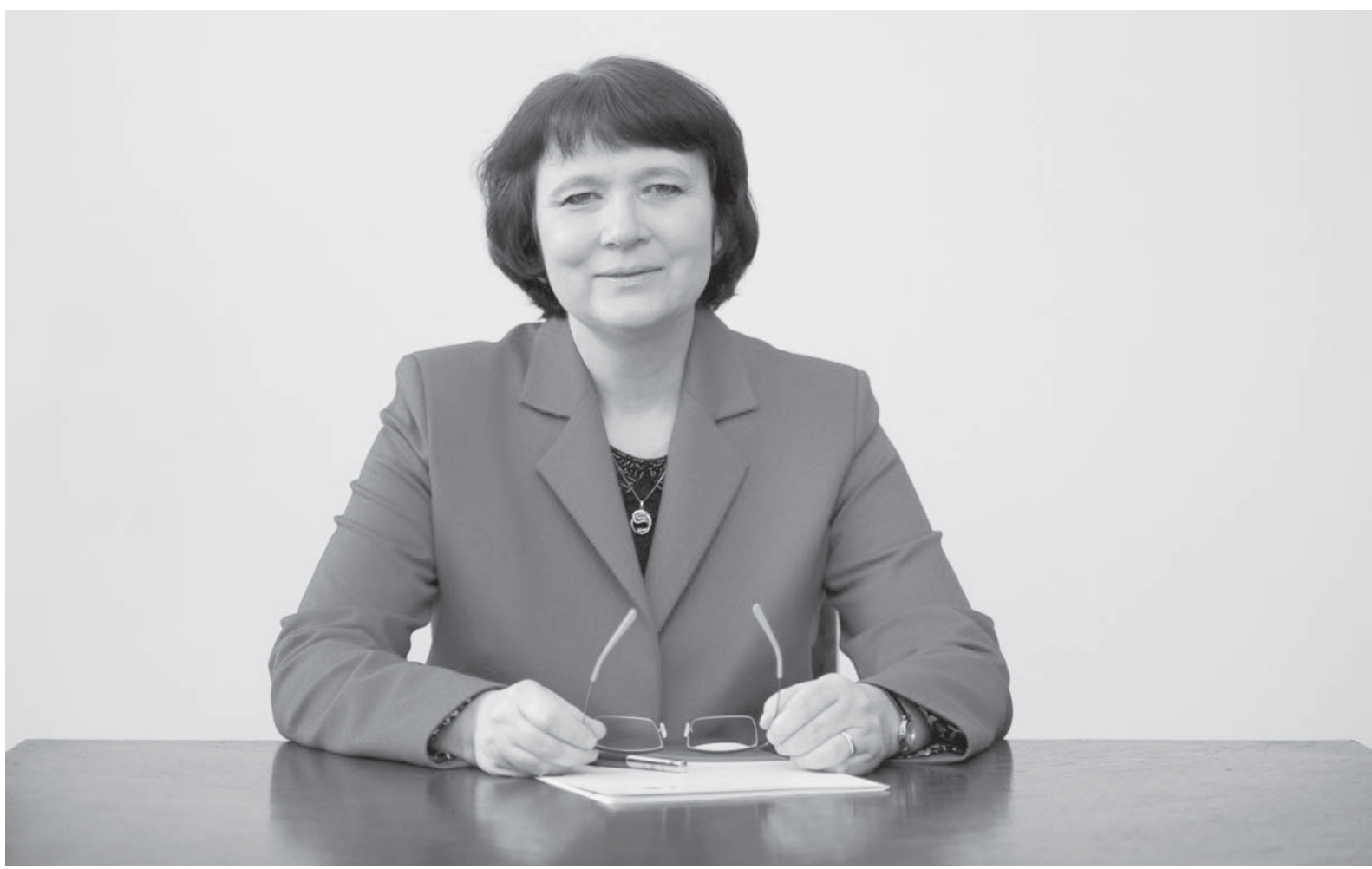

Photo Daniel Hamerník

ideas from young people and I believe that the companies can benefit from that.

\section{I do not understand then why companies hesitate in terms of cooperation.}

It also means a lot of work. If you want to invest into students, you need to release information, and the cooperation is good or bad depending on the managers - if they enjoy the cooperation and have a relationship with the university - in such cases, the results are very good. Another example is in Plzeňský Prazdroj where we have excellent cooperation - we can make various presentations, summer internships, etc. with them. Each time it is about the personal engagement of someone from the particular company.

\section{The University of Economics, Prague has also over 700 lecturers. What is the relationship of the lectu- rers and companies?}

It depends on what classes the lecturer gives. When they lecture on mathematics, there are not many opportunities. In case they give classes on marketing, then the cooperation with companies is very appropriate; otherwise, they do not get information they need. Development proceeds incredibly fast. It is the aim of the lecturer him/herself to have his/her own contact points within the companies. In the subject of International Marketing, for example, we have excellent cooperation with the $3 \mathrm{M}$ company, with whom we participate in semester projects. Students can go to their innovations center for consultations and so on. We have excellent cooperation with L'Oreal, and I believe that all of us put our best efforts in to getting into direct contact with companies. Anyone who does not do this cannot teach well - at least any subject with a practical focus.

\section{Do any managers from big companies come to the University of Economics, Prague for advice?}

We face the problem that the University of Economics, Prague still has the image of an educational institution and number of managers, unfortunately including some of our graduates, think that they cannot find adequate professionals or skilled people here who would be able to offer something practical. The truth is that not every lecturer out of the 700 is able or willing to cooperate with some companies - actually except for some bright individuals.

And do you think that companies might not be concerned to come and knock with a request for help when solving any particular problem? 
I believe that nowadays we are already able, mainly thanks to the young generation of experienced lecturers, to offer cooperation of high quality. In the nineties, we used to have the problem that our generation was leaving for business. My former schoolmates are nowadays at important managerial positions, e.g. in Deutsche Bank, PWC, etc. those who were left were mostly the big supporters of education or lecturers from the era of Socialism, which caused harm to the reputation. It has taken some time to educate young professionals.

\section{How about foreign countries - how does it work there?}

It depends on the type of university. In France, there are public universities and also business-focused universities, which are of a predominantly private character. The private universities are of different type that ours. Here their reputation is worse than that of public universities. However, over there, everything is the other way round. Top universities such as HEC or ESSEC are private and highly selective institutions possessing tight connections with the private sector. Public universities have mostly institutes of business administration (IAE) and these seek the tightest possible cooperation with the private sector (compulsory internships within the duration of at least six months). However, we share a common problem with them - mostly the number of students is high. When there are 2500 students graduating in one year, how can I find an internship for each of them? Private universities are in better position regarding that because they have 200 students per year at a maximum. The mass character is, therefore, one of the most serious issues.

\section{How is the University of Economics, Prague perceived compared to foreign universities?}

I believe that our position is favorable. We profit from the good reputation we have abroad. This is given by the fact that University of Economics, Prague sends its best students abroad. Our students are highly interested in studying abroad and we apply strict selection criteria. The selection criteria for studying abroad include grades, language certificates, whether or not the student has taken any subjects in a foreign language, if he/she provided assistance to a foreign student (buddy) and a general test. The students we send abroad are characterized by such high quality that our foreign partners think that all our students are equally good. Thus, they promote our reputation. Since we have been sending students abroad, it has never happened to us that any of them would fail abroad or would cause shame. The best ambassadors of our university abroad are our students. In addition to this, we have succeeded in becoming members of CEMS, which is indeed a prestigious network of business universities all around the world. Thanks to this, we are rated at the Financial Times Rankings. Therefore, due to our connection to the network of best universities and thanks to the fact that our best young and dynamic lecturers participate, our good reputation abroad is generated. Out of the CEE universities, it is only VŠE, University of Corvenius, Warsaw School of Economics in Poland, and St. Petersburg University included. This is an example of what an excellent reputation we have. We face the opposite problem compared to other universities because we have to refuse parties interested in cooperation with us. We select our foreign partners carefully and our strategy is cooperation with universities that are at least as good as we are or even better. Our partner network includes top universities from all around the world. Our reputation abroad is even better than within the Czech Republic, in my opinion.

\section{What are the specifics of the Czech Republic, or Central Europe, in the world-wide context? Are the managers different in some aspect?}

First of all, we smile too little. Our students are responsible and serious in my opinion. When I teach here I know they are on time for classes, they take notes and they do not ask questions. We are still facing obstacles in openness, communication; we are ashamed to ask in public. When I give lectures in France, I manage to finish with half of the content compared to here because the students keep asking questions and they take the classes as an opportunity to show off in front of the others, which makes the classes more lively and interesting. I do not like very much that our students do not greet people for example or that they are ashamed to say hello. We also smile too little at each other. I could take the example of the privatization of Komerční banka by the French partners. Both parties were coming to me and were surprised at the way the other party functioned. The Czech party used to say: "There was excellent Czech management here having a clear idea of what they wanted. We were given tasks and we were fulfilling them. However, the French do not know what they want. They keep asking us our opinion“. And the French used to say: „It is unbelievable: We ask their opinion because we want to encourage discussion, and the Czech people do not say anything. However, once the meeting is finished, they keep coming and giving us their advice“. And this is it. Or the problem of closed and open doors - when we walk around the university in France, everybody has the door open. We all keep them closed so as not to be disturbed. So there are specifics, but on the other hand, it is true that a Czech 
employee possesses the advantage of being very honest, hardworking, disciplined and creative. But alas, when you ask them to go for work from Prague to Brno...

1200 employees - To manage such a company, one has to be a manager. What type of manager are you and what is important for you?

Positive motivation is an important feature for me. I believe things can only work in a positive environment, when you influence others by your own diligence and your own results. Then they follow you. Recently I have finished at the post of department head. This department was very special in the regard that it had a lot of young people who stayed because I have always attempted to create opportunities for them. For example, so that they did not leave to lecture at private universities, I arranged classes in France and Austria. I tried to build up possibilities for giving lectures in English, which is paid extra, because I think that this is also excellent experience. Therefore, I think that positive motivation but also teamwork is needed. Altogether, we have six faculties here. Each of them has its own interests and there is competition between them. My predecessor, Professor Hindls, managed to smooth off the rough edges, and I think that mainly during the last four years it has been about cooperation and that also the faculties understood that the power is in unity and it is not worth competing amongst themselves but that our competition is somewhere else, outside. I would like to continue in this. Another important feature is determination, which is essential for this post and it is impossible to avoid this responsibility.
Central European Business Review is a periodical that introduces new opinions on many things. Can you tell us what you like about it? And why does it make sense?

We missed a periodical with a focus on business within the university. We have two impact periodicals at the university, Political Economy and Prague Economic Papers. Even from the titles, it is evident that they are not mainstream orientated as at least $80 \%$ of our students are business focused. We are happy to have impact scientific periodicals but sometimes I feel that these are journals that everybody writes articles for but nobody reads them. I would be glad if CEBR would be a periodical for which everybody writes but that is read a lot at the same time. I view the readership as essential, and I think that it is very interesting for our readers to learn about the view of the academic sphere into the business world and to experience the openness we have. We try to invite our colleagues from abroad into this periodical and I think that this is a unique thing. I think that this is the very first true international periodical of this university. And the companies should find up-to-date findings, results from our research and many other interesting things in it.

Author

Tomáš Poucha

Marketing Institute

Faculty of Business Administration University of Economics, Prague Nam. W. Churchilla 4, 13067

Prague 3, Czech Republic tpoucha@mkti.cz 